\title{
Exports of Services, Exports of Goods, and Economic Growth in Developing Countries
}

\author{
Alberto Gabriele \\ World Food Programe
}

\begin{abstract}
This paper explores quantitatively the nexus between GDP growth and the two components of total exports, focusing particularly on the role of services exports in developing and transition countries. The Introduction exposes some of the shortcomings and methodological problems affecting BOP statistics on international trade in services, and briefly describes the main trends in international trade in services. Econometric analysis in the following sections shows that, in the long run, services exports do have a positive impact on GDP growth in developing countries. Yet, for developing countries, the services exports/ GDP growth nexus is weaker than in the case of developed countries. Moreover, in most developing regions, the growth-enhancing impact of exports as a whole appears to have declined in the 1990s, although this decline appears to be due more to the merchandise component of exports rather than to the services component. In the conclusions, a tentative explanation for the aforementioned results is proposed. Export-oriented services activities in developing countries are often under the control of foreign economic agent, and they tend to be poorly integrated to the rest of the domestic economy. Thus, their potential as engines for growth is relatively weak. Moreover, many previously inward-oriented developing countries, under conditions of financial duress, diverted resources towards exports as a goal per se, rather than in the framework of a comprehensive long-term growth-maximizing strategy. Such opening-up reforms ended up facing
\end{abstract}

\footnotetext{
*Corresponding address: Alberto Gabriele, World Food Programe, Via Geasre Glulio Viola, 68/70, Parco de Medeci 00148 Roma, Italy, E-mail: Alberto.Gabriele@wfp.org (C2006-Center for International Economics, Sejong Institution, All Rights Reserved.
} 
diminishing returns.

\section{- JEL classification: F15}

- Keywords: Export-oriented servieces, Growth, Developing Countries

\section{Introduction}

This introductory section, based on Gabriele (2004), examines briefly the limitations of presently available official statistics on international trade in services and sketches its main trends during the last two decades of the XXth century.

The main reasons for the above-mentioned statistical inadequacy are three, all of them stemming from the peculiar nature of services as tradable economic activities. The most important is that the GATS typology, based on four modes of supply, is not matched so far by existing statistics, especially with respect to mode 3 (commercial presence). As a result, most statistics on trade in services fail to capture local sales of services by foreign firms. A fortiori, they do not distinguish exports of services carried out by nationals or by foreign enterprises, respectively. The other two reasons stem from a divergence in classification criteria between existing statistics on trade in services and the GATS commitments (mostly based on the GNS classification ${ }^{1}$ ), and more broadly from the impossibility (so far) of matching statistically the GATS distinction among the four modes of supply (see WTO 1997, part II).

Statistical coverage on trade in services is improving, and the Inter-Agency Task Force on Trade in Services Statistics is developing a common manual which will represent a significant step forward in striving to improve coverage and accuracy of services statistics. However, statistical reporting on trade in services is not likely to match the breadth and precision of statistics on merchandise trade in the foreseeable future, due, among other things, to methodological problems, a major one being the difficulty in distinguishing between price and volume data in services production and $\operatorname{trade}^{2}$ (see WTO 2000, para V). The evaluation of

\footnotetext{
The GNS classification is largely based on the UN-CPC classification but deviates from the latter in telecommunication, financial, and transport services.

${ }^{2}$ It is more difficult than in the case of merchandise trade to determine to what extent an increase in trade for a particular services sector is due, respectively, to: changing in relative prices; diverging variations in the exchange rate and in inflation among trading partners; improvements in product quality; changes in infra-sectoral product composition; "true" quantitative increases in trade volumes (WTO 2000, p.17).
} 
statistics on services export stemming from developing countries in a "development perspective", in particular, requires additional prudence, as it is impossible at the present stage to disentangle systematically which share of increasing export receipts from a service sector in a developing country (i.e., tourism) accrues to national firms and which to foreign affiliates of TNCs. If the bulk were to be captured by the latter (as it is often the case), it is clear that the positive development impact of the expansion of that particular services sector would be far lower than if national firms were the main agents driving the sector's export-oriented growth.

In practice, for the time being, the only comprehensive and consistent statistical source on international trade in services is constituted by the IMF Balance of Payments (BOP). This paper, therefore, utilizes as a source BOP data made available on-line by WTO and UNCTAD. ${ }^{3}$ These data, in spite of their shortcomings, are consistent and internationally comparable, and can also usefully be related with other basic macroeconomic statistics such as total GNP, total exports, and the like.

BOP data show that international trade in services has being expanding rapidly since the 1980s, outpacing on average both world GNP and world merchandise trade growth. However, this expansion slowed in the 1990s, due to mainly to an abrupt deceleration in the second half of the decade.

Until recently, starting from a low base, the growth in services exports has been faster in developing countries (DNCs) ${ }^{4}$ than in developed countries (DDCs). DNCs' share of world services exports reached about $1 / 4$ by the end of the century. Yet, in the late $1990 \mathrm{~s}$, the growth rate of services exports roughly halved both in DDCs (from 6.7\% in 1990-1995 to 3.6\% in 1995-2000) and in DNCs (from 12.15 in $1990-1995$ to $5.9 \%$ in 2000). As a result, contrarily to the experience in DDCs, where services have being playing an ever-increasing role, by the year 2000 the weight of services in DNCs' total exports was 14.6\%, lower than in 1995 (15.5\%) and even than in $1990(15 \%)$. Imports of services on the part of DNCs also decelerated markedly, negatively affecting their overall growth and development prospects.

${ }^{3}$ Most BOP statistics on trade in services were reported according to the concepts and classification system of the $4^{\text {th }}$ edition (1977) of the IMF Balance of Payments Manual (BPM-4). A transition is now occurring to the conceptual framework and the criteria of the $5^{\text {th }}$ edition of the manual (BPM-5). With respect to BPM-4, BPM-5 is more disaggregated and relatively less discordant with respect to GNS.

${ }^{4}$ Country grouping in this paper follows the UNCTAD database methodology, that classifies some republics formerly belonging to Yugoslavia as European developing countries. In the remainder of the paper, the term "transition countries" refers to all other ex-Soviet and Eastern European formerly socialist countries. 
Among developing countries, the most successful in expanding services exports were Asian DNCs, who recorded a growth rate of over 14\% up to the mid-1990s, although slowed down markedly afterwards. In spite of this slowdown, Asian DNCs' share of world services exports in 2000 was $18 \%$, more than twice as in 1980 and corresponding to $2 / 3$ of total services exports from developing countries. Latin America's and Africa's shares were much lower (4\% and 25 respectively) ${ }^{5}$.

Major exporters of services among developing countries broadly tend to coincide with major semi-industrialized merchandise exporters ${ }^{6}$, although there are several cases of developing countries with relatively modest merchandise export performances - such as Turkey, Egypt, and Paraguay - who have successfully specialized in exporting certain types of services. Consistently with the overall level of development of their national economies, and contrary to the case of industrialized countries - where new, technology- and human capital-intensive services sectors have boomed in the recent past, and have captured an everincreasing share of world trade - exporters from DNCs are relatively stronger in traditional, slow-growing services markets (Langhammer 2002), notwithstanding the relevance of some interesting exceptions (the most relevant being that of India and various other DNCs in the domain of IT-based services).

The remainder of this paper, identifying exports of services as an independent variable distinguished from the exports of goods, analyzes the nexus between the two components of total exports, on one hand, and GDP growth, on the other hand, focusing particularly on the role of services exports in developing and transition countries.

\section{The Complex Nexus ${ }^{7}$ between Exports and Growth}

Growth of services exports, not differently from growth of merchandise exports, should not be considered as a goal per se, but as an instrument in contributing to the achievement of broader economic and social development, especially in

\footnotetext{
${ }^{5}$ Latin America's share of world services exports declined in the 1980-2000period, , while that of Africa increased slightly.
${ }^{6}$ Some transition countries, thanks to their large industrial base, are also relatively strong exporters of some types of services.
${ }^{7}$ The term "nexus" suggests a complex, "rich" relationship structure between two (or more) economic phenomena (see Akyuz and Gore (1996) on the "investment-profit nexus" in East Asian industrialization).
} 
developing countries. To this respect, the shortcomings of GDP growth as an overall development indicator are well known. However, even where, as a working assumption, GDP growth is assumed as the only ultimate goal of economic policies, the degree of priority to be accorded to the intermediate goal of export expansion is a matter of controversy. In fact, on one hand, few analysts would deny that the indiscriminate expansion of at least some kinds of exports (i.e., those based on non-renewable natural resources) might in fact be inimical to long-term economic growth - and even more to the broader goal of sustainable development. On the other hand, even fewer, if any, would advocate a fully autarkic growth strategy. However, between these two extremes, the evaluation of the growthenhancing potential of exports, relative to other economically and socially relevant factors, is a matter of controversy. By the same token, opinions diverge on the question of exactly which role is to be assigned to exports in developing countries' overall growth strategy.

The so-called Export-Led Growth (ELG) hypothesis is at least as old as the classical school, as both Adam Smith and David Ricardo supported it (Richards 2001). Among modern economists, Beckerman (1965) attributed exports' favorable impact mainly to the production efficiency gains stemming from improved resources allocation, while Haberlar (1959) stressed the relevance of dynamic benefits, such as the improved availability of foreign capital and technology through the release of the balance of payments constraint. Vernon (1966) focused on the opposite causality channel, in which the self-propelled growth of the domestic economy leads to improved competitiveness and eventually to the expansion of exports. More recent "endogenous growth" theories emphasize the benefits stemming from a dynamic export sector, in a framework characterized by increasing returns to scale and by virtuous technological and managerial spill-over effects towards other sectors (Fedor 1992). Helpman and Krugman (1985) develop some of Beckerman's and Vernon's ideas, arguing that the initial growth spurt favoured by export expansion through the efficiency and allocation effects reverberates in enhanced international competitiveness, fostering a new round of export expansion and paving the way for a virtuous development path.

After several decades and the accumulation of an ever-expanding body of research literature, however, "No consensus has emerged on the theoretical appropriateness of the export-led growth hypothesis...Theoretical disagreement on the role of exports is matched by mixed empirical evidence" (Jin 2002, p.64; Richards 2001). To this respect, it must be taken into account that attempts to show 
econometrically that exports are a crucial cause of growth face two basic problems. First, exports are themselves a component of GDP, and thus evidence of a correlation is insufficient to prove consistently any actual causal relationship which might in fact exist. Second, other relevant macroeconomic variables, and especially other components of aggregate demand, are also correlated with GDP growth, and thus a missing variables problem of model mis-specification inevitably arises (Sheehey 1990) ${ }^{8}$.

The prevalent conclusion of the numerous studies on developing countries ${ }^{9}$ (see, for instance, Balassa (1978); Jung and Marshall (1985); Ram (1985); Chow (1987); Jin (1995); Levin and Raut (1997); Bahmani-Oskoee et al. (1991); Sharma and Dhakal (1994); Khalifa Al-Youssif (1997); Shan and Sun (1988); Biswal and Dawan (1988); Islam (1998); Glasure and Lee (1999); Ekanayake (1999); Jin (2002); and the surveys by Edwards (1993) and Giles and Williams (2000)), which employed various different methodologies, tend to support Helpman and Krugman's view. Both bivariate and multivariate models are generally supportive of the existence of a Granger causal ordering from exports to growth, although a feedback effect in the opposite (from growth to exports) direction is also apparent.

This body of research, most of which focused on fast-growing Asian developing countries, shows that exports can indeed be shown to act as an engine of growth in many cases, but a feedback relationship between growth and exports also tends to hold. One of the most recent examples is Chandra (2003), who showed that in India exports and GDP are cointegrated ${ }^{10}$, and the long-run causality from income to exports is indeed stronger than that from exports to income.

However, in other cases, the pattern of causality, or even the existence of a robust link between exports and growth, could not be demonstrated. The relationship between exports and growth appears to be particularly weak in the

\footnotetext{
${ }^{8}$ The story of the ELG hypothesis bears some resemblance to that of the "openness" story. In the latter case, attempts to "demonstrate" econometrically in a simplified fashion that one single factor, the "openness" of trade policies, could explain most of the variability in GDP growth performance among developing countries, have been shown to fail to pass a rigorous econometric scrutiny (Rodriguez and Rodrik 1999). Similar difficulties are the symptom of a deeper epistemological fallacy, common to all analytical approaches which aim to explain complex and diverse social and economic phenomena by means of a standardized and reductionist formal model.

${ }^{9}$ Many of these studies did not deal satisfactorily with the two crucial methodological problems raised by Sheehey (Richards 2001).

${ }^{10}$ Chandra used the terms of trade as an additional variable, finding it is also cointegrated with exports and GDP.
} 
studies focusing on countries which, as opposed to the extensively researched Asian NICs (and, to a lesser extent, to larger Asian countries such as India and China), did not manage to overcome the intersectoral disarticulation and the structural lack of economic homogeneity, which are typical marks of underdevelopment. This is the case, for instance, of Richards (2001). The author tested the ELG hypothesis for the case of Paraguay over the 1966-1996 period, using several time series methods, such as the Granger causality test, error correction modeling, and vector autoregression. His conclusion does not support the ELG hypothesis: “...there does not appear to be econometric evidence that Paraguayan export activity is characterized by a dynamic that is transferred to other sectors of the economy in the manner often ascribed to export production for other less developed countries, such as the Asian NICs. This finding has important implications for the study of the linkage between exports and economic growth generally speaking..." (p. 143). Also Catao (1998) failed to confirm the validity of the ELG hypothesis for the case of Mexico under the Porfirio Diaz regime (18771911).

\section{Exploring the Exports-Growth Nexus: Methodological Issues}

The brief review in the preceding sub-section confirms that the reciprocal interrelations among exports and GDP growth, and also the relative weight to be accorded to either of the two main causal linkages (from exports to GDP, or the opposite way round) are a matter of considerable dispute in theory, and can only be exhaustively explored empirically in the framework of a comprehensive analysis of each specific national economy, with the help of a properly constructed econometric model.

In this paper there is no attempt to carry out such an exhaustive model-based analysis. Our approach is consistent with "the researcher's view," suggested by Mela and Kopalle (2002), as opposed to the "alternative view" which assumes the "existence of a known linear additive relationship that is indeed the true underlying process that generates the $y$ " (p.670). According to Mela and Kopalle, "While the researcher may or may not control the $\mathrm{X}$ (observations of independent variables), the true process by which the corresponding observations of the dependent variable, $y$, are generated is unknown to the researcher. Thus, the researcher hypothesizes a linear additive model as a paramorphic representation of the process that generates the $\mathrm{y} . .$. In this view, the parameters including $\sigma 2$ are determined by 
the data" (p.670). Consistently with these caveats, the results of the following econometric exercise are to be seen in the framework of a correlation analysis, rather than as the testing of a regression model proper. Therefore, taking into account that in real-world economies the export/growth linkage is complex and includes, among other things, feedback effects, my goal is not to prove the existence of a causal relationship between services exports and GDP growth (in fact, there are no a priori theoretical reasons to deny it). Rather, comparing in a relative fashion the estimates of their reciprocal correlation parameters, I try to shed some light on the magnitude and relevance of the services exports/GDP growth "nexus".

In other words, exports, and services exports in particular, are seen as an "engine for growth" only in a very broad and far from exhaustive sense. The existence of a causal linkage from growth of services exports (as a component of total exports) to GDP growth is assumed ex ante and, in fact, is not falsified ex post by the results. However, the latter only synthesize statistically the product of a myriad of complex macroeconomic interactions, some of which are likely to be causal linkages running in the opposite direction, from GDP growth to export expansion. This statistical exercise, therefore, can only contribute to estimate empirically the magnitude of the above-mentioned statistical relationship between growth of services and merchandise exports, on one hand, and GDP, on the other hand, and more importantly - to explore its variations, if any, across the various groups of countries analyzed over different periods. ${ }^{11}$

Finally, we refer to the issue of collinearity. The consequences of collinearity depend essentially on two factors: (1) whether the "true" model is known, and the correspondent variables are available; (2) whether the regression analysis is predicated upon a sample or upon the entire population (Mela and Kopalle 2002). With respect to the first factor, in the present analysis the imperfect specification of the underlying model ${ }^{12}$ is taken for granted. Thus, collinearity is bound to generate a variable omission bias and (possibly) an inclusion of irrelevant variable bias. ${ }^{13}$

\footnotetext{
${ }^{11}$ As Chandra (2003) pointed out, the issue of causality can only be addressed in a time-series framework. Such an approach, due inter alia to the paucity of data, is not attempted in the present study.

${ }^{12}$ Consistently with the "researcher's view" mentioned above, in fact, the regressions are not based on a "model" in the proper sense of the word, but only in the sense of a simplified, linear statistical specification of the exports/GDP nexus..

13،"Following Johnston (1984, p. 260), it is noted that the effect of omitting j relevant variables ...biases the parameter estimates for the remaining P-j variables" (Mela and Kopalle 2002, pp.699-670).
} 
However, Mela and Kopalle (2002) also show that, in regressions where all correlation coefficients between the dependent and the independent variables are positive (which is the case in our analysis), "negative correlations among the independent variables have a much greater impact on variable omission bias than equivalent positive correlations" (p.675). As collinearity between the growth rates of services exports and those of merchandise exports is always positive, the bias in the estimated parameters and the deterioration in the overall fit of the regressions which might be assumed to have been caused by the variable omission problem is relatively less important than it would be otherwise. With respect to the second factor affecting the potential bias implied by collinearity, it should not apply to the present analysis, as the latter is predicated virtually upon the entire population (all countries in the world for which data are available). Therefore, the estimates of the parameter variance are expected to be substantially correct.

\section{Data and Variables}

Taking into account the significant limitations still affecting both the availability and the reliability of data on services exports (see Section 1), a group of 114 countries (all those for which WTO data on services exports were available for the year 2000) was selected to constitute the basic sample group. The basic sample group was further divided into six sub-groups: Developed countries (DVD, countries 1-24); Latin America (LA, countries 25-45); Africa (AFRICA, countries 46-66); Near East and Mediterranean (NEMED, countries 67-76); East Asia and Pacific (ASIA, countries 77-95); Transition countries (TRANS, countries 96$114)^{14}$.

The analysis covers the 1980s and the 1990s, focusing first on the whole 19802000 period and then on each of the two decade-long periods 1980-1990 and 1990-2000. Coefficient estimates are expected to be less than fully precise, as they are influenced, among other things, by the scale effect caused by outliers ${ }^{15}$.

\footnotetext{
${ }^{14}$ As consistent data for the TRANS sub-group are only available for a few countries and not for all years, these 18 countries were in fact excluded from all but three of the models.

${ }^{15}$ Distortions are stronger for countries that experience disturbances, turmoil and less stability. Therefore, they are likely to affect more severely parameter estimates for developing rather than for developed countries. Most outliers, in fact, are small developing countries exhibiting exceptionally high or low growth rates of either exports or (less frequently) GDP, due to country- and period-specific causes different from the underlying, structural export/growth nexus.
} 
For each period (sub-period) the growth rate of GDP was taken as the dependent variable. On the right end side, the growth rates of services and merchandise exports are taken as the core explanatory variables.

The base equation, with all variables expressed in logs, can be expressed as follows:

(1) $d\left(\ln G D P_{i}\right)=\alpha+\beta d\left(\ln E X P S E R V_{i}\right)+\delta d\left(\operatorname{lnEXPGOODS_{i})+\varepsilon }\right.$

where EXPSERV and EXPGOODS represent exports of services and goods respectively, ${ }_{\mathrm{i}}$ denotes exporting countries, $\mathrm{d}$ is the difference operator, and $\varepsilon$ is an error term. As the core explanatory variables are expressed in logarithms, the coefficients $\beta$ and $\delta$ can be interpreted as proxies for the elasticity of GDP with respect to the exports of services and goods.

In order to control for the robustness of the results, the impact on growth of two other sets of variables, along with the two core ones, was also investigated ${ }^{16}$. The first set was constituted by standard economic, social, and demographic variables, which are believed in theory to have an impact on GDP growth. In the framework of the present statistical approach, only two of these variables turned out to be significant ${ }^{17}$ : the investment ratio (proxied by the average gross fixed capital formation ratio) and the initial per capita GDP in $\log$ form. ${ }^{18}$ The resulting augmented

\footnotetext{
${ }^{16}$ Consistently with the caveats exposed in Sub-section 3.3., the inclusion of these control variables is not to be seen as an attempt to build a comprehensive model capable of explaining fully the diverse countries' growth performances.

${ }^{17}$ Besides GFKF and lnPCGDP, the following explanatory variables were tried (either in levels or in log form), but turned out to be either unavailable for a sufficient number of countries or not significant: primary, secondary and tertiary school enrolment rate (total and female, gross and net); illiteracy rate (total and female); population density (initial, 1980); population total (initial, 1980); population growth (average, 1980-2000); debt service ratio (debt service as a percentage of exports, average 1980-2000); share of services in GDP (initial, 1980). Many of these variables have been utilized in other studies in the framework of previous empirical exercises (see, for instance, Barro 1997), producing varying results according to the specific analytical framework in which they were carried out.

${ }^{18}$ InPCGDP80, in particular, exhibits a strong negative (and thus theory-consistent) coefficient. The magnitude of the convergence effect (ie, the often-assumed tendency for growth to be faster in poorer countries), however, should not be over-emphasized, due mainly to two reasons. First, owing to high population growth in most developing countries, a faster growth of total GDP in poorer than in richer countries does not necessarily translate into a closing up of the GDP per capita gap (not measured in the present model). Second, as mentioned below in the main text, once regional dummies are added to the regression, the convergence effect loses significance, suggesting it was essentially confined to the strong performance of only one developing region, Asia.
} 
equation is:

(2) $d\left(\ln G D P_{i}\right)=\alpha+\beta d\left(\operatorname{lnEXPSERV_{i}}\right)+\delta d\left(\operatorname{lnEXPGOODS_{i}}\right)+\lambda\left(G F K F_{i}\right)+$ $\phi\left(\ln P C G D P_{i}\right)+\varepsilon$

where (for each period) $G F K F$ represent the average gross fixed capital formation ratio, and $P C G D P$ the initial per capita GDP. ${ }^{19}$

The second set of variables was formed by the six regional dummies (DVD; $L A$; AFRICA; NEMED; ASIA; TRANS) and by the dummy DNC for all developing countries (countries 25-95) ${ }^{20}$. Dummy variables were tested both in the additive and the slope form. The specification of the additive dummy models is:

$$
\begin{gathered}
(3) d\left(\ln G D P_{i}\right)=\alpha+\beta d\left(\ln E X P S E R V_{i}\right)+\delta d\left(\ln E X P G O O D S_{i}\right)+\lambda\left(G F K F_{i}\right)+ \\
\phi\left(\ln P C G D P_{i}\right)+\eta(D U M M Y i)+\mu\left(D U M M Y_{i i}\right)+\ldots .+\varepsilon
\end{gathered}
$$

where $\mathrm{i}, \mathrm{ii}, \ldots$ vii indicate the seven regional dummies (not all of which are necessarily present in each of the models $)^{19}$.

The only dummy variable tested in the slope dummy models was $D N C$, as these models were tested in order to further explore the differences (in the core functional relationships) between developed and developing countries. The specification of the slope dummy models is:

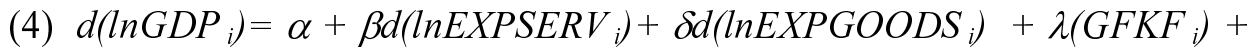
$\phi\left(\ln P C G D P_{i}\right)+\eta\left(D N C^{*}\left(d\left(\ln E X P S E R V_{i}\right)\right)\right)+\mu\left(D N C^{*} d\left(\ln \left(E_{X P G O O D S_{i}}\right)\right)\right)+$ $\left.v\left(D N C^{*}\left(G F K F_{i}\right)\right)+\theta\left(D N C^{*} \ln P C G D P_{i}\right)\right)+\varepsilon$

\footnotetext{
${ }^{19}$ Both the capital formation ratio and the initial GDP per capita were added to the equation in order to control for their impact on the significance and coefficients of the two core variables (services and merchandise exports). Therefore, there was no need to interpreter the coefficients of the control variables as elasticities. Moreover, as their value, by construction, was the same (for each country) for each period considered, they could not have been expressed in growth rate (i.e., $d(\ln )$ terms.

${ }^{20}$ Dummy variables' values are 1 for the countries belonging to each group and 0 for all the other countries.
} 


\section{Results}

\section{A. The 1980-2000 period}

The first series of regressions was run on all sample countries over the entire 1980-2000 period. Its main goal was to verify the existence of a broad statistical relationship between the growth rates of services exports and GDP, and to explore how it was influenced by the inclusion of other explanatory variables, such as the growth rates of merchandise exports and other control variables.

The first regression is a trial one, with the rate of growth of GDP as the dependent variable (just as in all the other models), and the rate of growth of services exports

Table 1. Results: Period:1980-2000

\begin{tabular}{|c|c|c|c|c|c|}
\hline Models & Explanatory Variables & Coefficient & t-Statistic & R-squared & F statistic \\
\hline \multirow[t]{4}{*}{1} & 114 countries & & & & \\
\hline & EXPSERV8000 & 0.2 & $4.09 * *$ & & \\
\hline & $\mathrm{C}$ & 1.76 & $5.68 * *$ & & \\
\hline & & & & 0.21 & 25.5 \\
\hline \multirow[t]{5}{*}{2} & 114 countries & & & & \\
\hline & EXPSERV8000 & 0.12 & $3.1 * *$ & & \\
\hline & EXPGOODS 8000 & 0.25 & $5.96 * *$ & & \\
\hline & $\mathrm{C}$ & 1.05 & $4.18 * *$ & & \\
\hline & & & & 0.5 & 44.9 \\
\hline \multirow[t]{7}{*}{3} & 114 countries & & & & \\
\hline & EXPSERV8000 & 0.1 & $2.3^{* *}$ & & \\
\hline & EXPGOODS 8000 & 0.2 & $3.35^{* *}$ & & \\
\hline & GFKF8000 & 0.08 & $2.29 * *$ & & \\
\hline & PCGDP80 & -0.25 & $-2.83 * *$ & & \\
\hline & $\mathrm{C}$ & 1.72 & $2.18 * *$ & & \\
\hline & & & & 0.56 & 22.7 \\
\hline \multirow[t]{12}{*}{4} & 114 countries & & & & \\
\hline & EXPSERV8000 & 0.11 & $2.86 * *$ & & \\
\hline & EXPGOODS 8000 & 0.12 & $2.02 * *$ & & \\
\hline & GFKF8000 & 0.05 & $2.09 * *$ & & \\
\hline & PCGDP80 & 0.1 & 0.76 & & \\
\hline & DVD & 1.01 & 1.15 & & \\
\hline & LA & 1.39 & 1.68 & & \\
\hline & AFRICA & 2.44 & $3.13 * *$ & & \\
\hline & ASIA & 3.69 & $3.77 * *$ & & \\
\hline & NEMED & 2.6 & $3.16^{* *}$ & & \\
\hline & $\mathrm{C}$ & -1.91 & -1.63 & & \\
\hline & & & & 0.77 & 23.6 \\
\hline
\end{tabular}


Table 1. continues.

\begin{tabular}{|c|c|c|c|c|c|}
\hline Models & Explanatory Variables & Coefficient & t-Statistic & R-squared & F statistic \\
\hline 5 & 114 countries & & & & \\
\hline & EXPSERV8000 & 0.1 & $2.6^{* *}$ & & \\
\hline & EXPGOODS8000 & 0.17 & $3.4 * *$ & & \\
\hline & GFKF8000 & 0.08 & $3.35 * *$ & & \\
\hline & PCGDP80 & -0.04 & -0.3 & & \\
\hline & DNC & 0.99 & $2.43 * *$ & & \\
\hline & $\mathrm{C}$ & -0.55 & -0.46 & & \\
\hline & & & & 0.6 & 19.7 \\
\hline 6 & 114 countries & & & & \\
\hline & EXPSERV8000 & 0.08 & 1.14 & & \\
\hline & EXPGOODS8000 & 0.22 & $2.31 * *$ & & \\
\hline & GFKF8000 & -0.003 & -0.09 & & \\
\hline & PCGDP80 & -0.33 & -1.12 & & \\
\hline & DNC*EXPSERV8000 & 0.02 & 0.26 & & \\
\hline & DNC*EXPGOODS8000 & -0.05 & -0.43 & & \\
\hline & DNC*GFKF8000 & 0.09 & $1.73 *$ & & \\
\hline & DNC*PCGDP0 & 0.3 & 0.9 & & \\
\hline & $\mathrm{DNC}$ & -3.72 & -1.33 & & \\
\hline & $\mathrm{C}$ & 3.97 & 1.55 & & \\
\hline & & & & 0.6 & 10.6 \\
\hline
\end{tabular}

*Significant at the $10 \%$ level

$* *$ Significant at the $5 \%$ level

(EXPSERV8000) as the only explanatory variable (Table 1 , Model 1$)^{21}$. The regression is significant, but the $\mathrm{R} 2$ is low (0.21), and the coefficient of EXPSERV8000 (0.2) is likely to be spuriously high as it captures to a large extent the impact of the missing variable "rate of growth of merchandise exports". In fact, when the latter (EXPGOODS8000) ${ }^{22}$ is added to the right end side, both variables turn out to be significant, and R2 rises to 0.5. Moreover, the coefficient of EXPSERV8000 falls to 0.12, about one half of the coefficient for the rate of growth of merchandise exports (Table 1, Model 2). This result shows that, besides

\footnotetext{
${ }^{21}$ As all the models have a cross-country structure, this regression, like all the others, was run using the White heteroskedasticity-consistent correction technique.

${ }^{22}$ The correlation coefficients between $\mathrm{d}(\operatorname{lnEXPSERV})$ and $\mathrm{d}(\operatorname{lnEXPGOODS})$ are high: 0.47 for 19802000, 0.49 for 1980-1990, and 0.41 for 1990-2000. This finding confirms the existence of positive collinearity between the growth rates of services and merchandise exports. Yet, the results of this exercise, with all the caveats referred to above, can be interpreted as basically correct according to the Mela and Kopalle's (2002) argument briefly exposed in Section 3.
} 
the previously mentioned issue of collinearity, the new variable is "dominant" with respect to the first one. This indicates that, in spite of the rise of services, the impact on GDP of merchandise exports still tends to be more relevant. ${ }^{23}$

Adding the investment ratio and the log of the initial per capita income, the coefficients of both EXPSERV8000 and EXPGOODS8000 change little, showing them to be robust with respect to the introduction of the new variables. R2 increases moderately (Table 1, Model 3).

The next step was the introduction on the right hand side of 5 of the 6 regional dummies $^{24}$ (Table 1, Model 4). As expected, the impact of the regional variables is strong, showing that region-specific factors tended to make growth quite high in Asia, and lower in the developed countries and Latin America, with Africa, the Near East and the Mediterranean countries in an intermediate position. It also has the effect of rendering insignificant the per capita GDP control variable (as was to be expected), as well as of lowering the coefficient of EXPGOODS8000, and of changing the sign of the intercept. The coefficient of EXPSERV8000 is virtually unchanged with respect to the previous model. R2 edges up to 0.77 . These results can be interpreted as follows. Region-specific factors (stemming particularly from Asia) were largely responsible for the income convergence effect evidenced by Model 3, and also contributed in rendering the elasticity of GDP growth with respect to the growth of merchandise exports uneven across the various world regions. The elasticity of GDP growth with respect to the growth of services exports, on the contrary, appears to have been similar in all the regions.

Other regressions were run to investigate the differences in the aforementioned structural relations between developed countries and the whole group of developing countries taken as a whole. When added to the base model, the intercept dummy variable, DNC, turns out to be significant, with a coefficient close to one, suggesting that factors other than those represented in the model accelerated growth in developing countries taken as a whole. As these factors largely coincide with those leading to income convergence, PCGDP8000 lost significance. The growth rates of both exports components and the investment

\footnotetext{
${ }^{23}$ In order to check this proposition, control regressions were run substituting EXPGOODS8000 to EXPSERV 8000 as the only explanatory variable. For all sub-periods and groups of countries, coefficients and $\mathrm{T}$ statistics were much higher than in the regressions where GREXPSERV was the only explanatory variable.

${ }^{24}$ The dummy variable TRANS was excluded because 1980-2000 data on most transition countries were not available. Consistently, c was kept in the model.
} 
ratio, however, proved robust, and did not lose their significance (Table 1, Model 5).

In the following exercise, four slope dummy variables were constructed, multiplying each of the explanatory variables by the intercept dummy DNC, and added to the base model. In the new control regression, Wald tests carried out on the sum of the original and the slope dummy variables' coefficients showed that those constructed from the first three explanatory variables were significant ${ }^{25}$. On the contrary, only EXPGOODS8000 maintains a high level of significance among the original explanatory variables. ${ }^{26}$ These findings suggest that the linkage between services exports and growth and (more clearly) the role of accumulation in the growth process were stronger for developing than for developed countries.

The results of the 1980-2000 models suggest that the relation between GDP growth, on the one hand, and the growth of merchandise and services exports, on the other, is significant and robust, and that the export elasticity of GDP is much higher in the case of goods than in that of services. The investment rate and the initial per capita income are also significant in explaining growth performances. The application of dummy variables techniques, along with the weight of regionspecific factors, shows that the structural linkages between growth and the explanatory variables were different, to some extent, in developed and developing countries respectively.

\section{B. The 1980-1990 period}

Another set of regressions was run over the two shorter 1980-1990 and 1990-2000 periods, in order to explore the changes - if any - in the GDP/exports nexus from one decade to the other ${ }^{27}$. For the 1980 s, the first to be tested was the base set of explanatory variables used in Model 3: the growth rates of services and merchandise exports, the average investment ratio, and the log of the initial of per capita GDP level.

The results are similar to those relative to the longer 1980-2000 period, but show higher values for F, R2, and the coefficients of the control variables, and slightly lower values for those of EXPSERV and EXPGOODS (Table 2, Model 7). Adding

\footnotetext{
${ }^{25}$ At the 5 per cent confidence level.

${ }^{26}$ Among the slope dummies, the coefficient of DNC*GFKF8000 was positive and significant at the 10 per cent level, that of DNC*GOODS 8000 was negative but not significant, and those of DNC*EXPSERV8000 and DNC*LOGGDPC80 were positive and not significant (Table 12, Model 6).

${ }^{27}$ Initially, trial regressions were also run for the short 5-year sub-periods 1990-1995 and 1995-2000. However, they did not produce significant and consistent results, due most likely to the very shortness of the sub-periods analyzed.
} 
Table 2. Results: Period:1980-1990

\begin{tabular}{|c|c|c|c|c|c|}
\hline Models & Explanatory Variables & Coefficient & t-Statistic & R-squared & F statistic \\
\hline & 114 countries & & & & \\
\hline \multirow[t]{7}{*}{7} & EXPSERV 8090 & 0.08 & $2.12 * *$ & & \\
\hline & EXPGOODS8090 & 0.17 & $4.2 * *$ & & \\
\hline & GFKF 8090 & 0.15 & $5.11^{* *}$ & & \\
\hline & PCGDP80 & -0.49 & $-5.35 * *$ & & \\
\hline & $\mathrm{C}$ & 2.3 & $2.87 * *$ & & \\
\hline & & & & 0.65 & 33.2 \\
\hline & 114 countries & & & & \\
\hline \multirow[t]{12}{*}{8} & EXPSERV 8090 & 0.08 & $2.17 * *$ & & \\
\hline & EXPGOODS8090 & 0.13 & $3.4^{* *}$ & & \\
\hline & GFKF8090 & 0.09 & $3.26 * *$ & & \\
\hline & PCGDP80 & -0.02 & -0.12 & & \\
\hline & DVD & -1.43 & -1.2 & & \\
\hline & LA & -1.58 & -1.36 & & \\
\hline & AFRICA & 0.18 & 0.17 & & \\
\hline & ASIA & 1.35 & 1.17 & & \\
\hline & NEMED & -0.94 & -0.8 & & \\
\hline & $\mathrm{C}$ & 0.57 & 0.39 & & \\
\hline & & & & 0.76 & 23.6 \\
\hline & 114 countries & & & & \\
\hline \multirow[t]{11}{*}{9} & EXPSERV 8090 & 0.01 & 0.13 & & \\
\hline & EXPGOODS8090 & 0.13 & $1.8^{*}$ & & \\
\hline & GFKF 8090 & 0.06 & 0.91 & & \\
\hline & PCGDP80 & -0.19 & -0.64 & & \\
\hline & DNC*EXPSERV8090 & 0.08 & 0.89 & & \\
\hline & DNC*EXPGOODS8090 & 0.04 & 0.48 & & \\
\hline & DNC*GFKF 8090 & 0.08 & 1.13 & & \\
\hline & DNC*PCGDP80 & -0.25 & -0.72 & & \\
\hline & $\mathrm{DNC}$ & -0.15 & -0.04 & & \\
\hline & $\mathrm{C}$ & 2.12 & 0.67 & & \\
\hline & & & & 0.66 & 13.9 \\
\hline \multirow[t]{8}{*}{10} & DVD 124 & & & & \\
\hline & EXPSERV 8090 & 0.01 & 0.12 & & \\
\hline & EXPGOODS8090 & 0.13 & 1.68 & & \\
\hline & GFKF8090 & 0.06 & 0.85 & & \\
\hline & PCGDP80 & -0.19 & -0.59 & & \\
\hline & & 2.12 & 0.62 & & \\
\hline & & & & 0.22 & $1.06(\mathrm{pr} 0.4)$ \\
\hline & DNC 2595 & & & & \\
\hline \multirow[t]{6}{*}{11} & EXPSERV8090 & 0.08 & $1.99^{*}$ & & \\
\hline & EXPGOODS8090 & 0.18 & $3.58 * *$ & & \\
\hline & GFKF8090 & 0.14 & $4.22 * *$ & & \\
\hline & PCGDP80 & -0.44 & $-2.71 * *$ & & \\
\hline & $\mathrm{C}$ & 1.98 & $1.8^{*}$ & & \\
\hline & & & & 0.67 & 25.1 \\
\hline
\end{tabular}

*Significant at the $10 \%$ level

**Significant at the $5 \%$ level 
the regional dummies to the right hand side (Table 1, Model 8), the log of the initial of per capita GDP level loses its significance, and the coefficient of EXPGOODS decreases (as they did in Model 4). Regional dummies' coefficients, however, are not significant. The slope dummy model and the Wald tests showed that the four explanatory variables are significant in the case of developing countries, but only EXPGOODS was significant ${ }^{28}$ in the case of developed countries. They also show that the elasticity of GDP growth with respect to EXPSERV, EXPGOODS, GFKF and LOGGDPPC was higher in developing than in developed countries, although not significantly so (Table 1, Model 9). These results were controlled, running two separate regressions on the group of 24 developed countries, on the one hand, and on that of 71 developing countries, on the other hand. The first regression fails to produce any significant result, while the second one shows that all the four explanatory variables were quite significant for the developing countries' group (Table 1, Models 10, 11).

These - someway surprising - results show that, during the 1980s, the theoryconsistent structural linkages between exports, accumulation, and initial per capita income held in a strong and robust fashion only for developing countries. GDP growth in developed countries, on the contrary, was not structurally related to these factors in a statistically significant way. They also imply that the growth-enhancing role of capital accumulation and the magnitude of the catching-up process on the part of poorer countries as a whole were more relevant in that decade than (on average) during the longer $1980-2000$ period.

\section{The 1990-2000 period}

In the 1990-2000 period the main explanatory variables are expressed as EXPSERV9000, EXPGOODS9000, GFKF9000, and PCGDP90 (per capita GDP in 1990) (See Table 3). In this period, only the growth rate of merchandise exports and the initial per capita income maintain their significance in the base model, with coefficients lower than in the previous decade. The growth rate of services exports and the investment rate turn out to be not significant (Table 3, Model 12). The fit and the explanatory power of the regression, as shown by the values of the Fstatistic and of the R2, are also lower than in the previous models. These differences are due in part to the fact that - thanks to the availability of data statistical information on a higher number of transition countries was included in

${ }^{28}$ At the $10 \%$ level. 
the 1990-2000 sample: a control regression run for the 95 non-transition countries also produced low $\mathrm{F}$ and $\mathrm{R} 2$ values and a not significant GFKF coefficients, but the growth rate of services exports turns out to be significant at the 10 per cent level (Table 3, Model 13).

Table 3. Results: Period: 1990-2000

\begin{tabular}{|c|c|c|c|c|c|}
\hline Models & Explanatory Variables & Coefficient & t-Statistic & R-squared & F statistic \\
\hline & 114 countries & & & & \\
\hline \multirow[t]{7}{*}{12} & EXPSERV9000 & 0.06 & 1.25 & & \\
\hline & EXPGOODS9000 & 0.15 & $2.7 * *$ & & \\
\hline & GFKF9000 & 0.06 & 1.38 & & \\
\hline & PCGDP90 & -0.22 & $-2.22 * *$ & & \\
\hline & $\mathrm{C}$ & 2.61 & 2.16 & & \\
\hline & & & & 0.33 & 8.9 \\
\hline & DVD,DNC 195 & & & & \\
\hline \multirow[t]{7}{*}{13} & EXPSERV9000 & 0.09 & $1.75^{*}$ & & \\
\hline & EXPGOODS9000 & 0.11 & $2.3 *$ & & \\
\hline & GFKF9000 & 0.05 & 1.35 & & \\
\hline & PCGDP90 & -0.25 & $-2.38 * *$ & & \\
\hline & $\mathrm{C}$ & 3.07 & 2.62 & & \\
\hline & & & & 0.38 & 10.5 \\
\hline & 114 countries & & & & \\
\hline \multirow[t]{12}{*}{14} & EXPSERV9000 & 0.07 & 1.26 & & \\
\hline & EXPGOODS9000 & 0.07 & 1.39 & & \\
\hline & GFKF9000 & 0.05 & 1.49 & & \\
\hline & PCGDP90 & -0.16 & -0.89 & & \\
\hline & DVD & 2.44 & 1.41 & & \\
\hline & LA & 2.98 & $2.14 * *$ & & \\
\hline & AFRICA & 2.23 & 1.65 & & \\
\hline & ASIA & 4.27 & $2.93 * *$ & & \\
\hline & NEMED & 4.23 & $2.7 * *$ & & \\
\hline & TRANS & -2.22 & -1.55 & & \\
\hline & & & & 0.57 & 9.7 \\
\hline & 114 countries & & & & \\
\hline \multirow[t]{4}{*}{15} & EXPSERV8090 & 0.13 & $2.33 * *$ & & \\
\hline & EXPGOODS 8090 & 0.3 & $3.74 * *$ & & \\
\hline & GFKF8090 & -0.08 & $-1.95^{*}$ & & \\
\hline & PCGDP80 & -0.25 & -0.93 & & \\
\hline ns & DNC*EXPSERV8090 & -0.04 & -0.51 & & \\
\hline ns & DNC*EXPGOODS8090 & -0.21 & $-2.22 * *$ & & \\
\hline ns & DNC*GFKF8090 & 0.14 & $2.49 * *$ & & \\
\hline \multirow[t]{4}{*}{ ns } & DNC*PCGDP80 & 7.56E-05 & 0.67 & & \\
\hline & $\mathrm{DNC}$ & -1.23 & -0.85 & & \\
\hline & $\mathrm{C}$ & 4.24 & 1.67 & & \\
\hline & & & & 0.44 & 5.5 \\
\hline
\end{tabular}


Table 3. continued

\begin{tabular}{|c|c|c|c|c|c|}
\hline Models & Explanatory Variables & Coefficient & t-Statistic & R-squared & F statistic \\
\hline & DVD 124 & & & \multirow{13}{*}{$\begin{array}{l}4 \\
4 \\
9\end{array}$} & \\
\hline \multirow[t]{7}{*}{16} & EXPSERV9000 & 0.14 & $2.6^{*}$ & & \\
\hline & EXPGOODS9000 & 0.3 & $3.67 * *$ & & \\
\hline & GFKF9000 & -0.09 & $-1.92^{* *}$ & & \\
\hline & PCGDP90 & -0.01 & -0.043 & & \\
\hline & $\mathrm{C}$ & 2.04 & 0.3 & & \\
\hline & & & & & 16.5 \\
\hline & DNC 2595 & & & & \\
\hline \multirow[t]{5}{*}{17} & EXPSERV9000 & 0.08 & 1.4 & & \\
\hline & EXPGOODS9000 & 0.09 & \multirow{2}{*}{$\begin{array}{c}1.6 \\
1.54\end{array}$} & & \\
\hline & GFKF9000 & 0.06 & & & \\
\hline & PCGDP90 & -0.07 & -0.34 & & \\
\hline & $\mathrm{c}$ & 1.92 & 1.19 & & \\
\hline
\end{tabular}

*Significant at the $10 \%$ level

$* *$ Significant at the $5 \%$ level

Adding the regional dummies, all explanatory variables lose significance. The TRANS variable, as expected, is negative, while all other dummies are positive. Three of them (LA, ASIA, and NEMED) are also significant at the 5 per cent level, showing that in the 1990s region-specific factors had a higher impact on growth than before (Table 3, Model 14). The results of the slope dummies model are at variance with those of the corresponding model relative to the previous decade. The Wald tests showed that all the explanatory variables' coefficients were not significant in the case of developing countries. Conversely, the coefficients of EXPSERV, EXPGOODS, and GFKF are significant in the case of developed countries. The latter, oddly, has the wrong sign. The GDP growth elasticities with respect to both services and merchandise exports are lower in developing than in developed countries, while the elasticity with respect to the investment ratio is higher (Table 3, Model 15). For EXPGOODS and GFKF, moreover, the differences in coefficients between developed and developing countries are large, to the point of being statistically significant at the 5 per cent level. As in the case of the 1980-1990 models, these findings were controlled, running separate regressions on the two groups of developed and developing countries respectively. The coefficients for EXPSERV and EXPGOODS are high and significant in the developed countries regression, low and not significant in the developing countries 
regression (Table 3, Models 16,17).

\section{Main Findings}

The results of the 1990-2000 models can be summarized as follows. In the 1990 s, services exports became a very significant factor ${ }^{29}$ in the growth performances of the developed countries. ${ }^{30}$ Conversely, in developing countries, the relationship between both services and merchandise exports, on one hand, and growth, on the other hand, lost statistical significance. Contrary to the 1980-1990 period, the elasticities of GDP with respect to the growth of both export components were higher in developed than in developing countries. These trends were particularly dramatic for the merchandise component of exports but affected services exports as well. In sum, the exports/GDP nexus became stronger in the developed countries but weaker in the developing countries. ${ }^{31}$

These findings indicate that, for developed countries, only during the last decade the growth of services exports - spurred, in particular, by the fast development of information-technology intensive services - began showing a strong and increasing impact on overall GDP growth. This is consistent with the ever more crucial role played by the services sectors in the developed economies, with services' growing articulation and reciprocal inter-relation with the other productive sectors, as well as with their increasingly traded nature. The picture is quite different in the case of developing countries. The role of services exports as a GDP growth engine was recognizable in the developing world already in the 1980s - albeit less clearly than that of merchandise exports - but in the following decade it appeared to vanish. Moreover, in the developing countries, the overall trade/growth nexus, which had been quite strong in the 1980s, was severely weakened over the 1990s. This breach was largely due to the disruptions caused by the international financial crisis of the late 1990 s, which were particularly concentrated on a small cluster of very

\footnotetext{
${ }^{29}$ See, in particular, the high value of R2 in Model 16.

${ }^{30}$ On the contrary, fixed capital accumulation appears to have played a marginal, if not perverse, role in the growth process of developed countries during the 1990s. This apparent statistical curiosum is due largely to the Japanese stagnation, but it might as well reflect to some extent the increased weight of technological and financial factors.

${ }^{31}$ Indicative results from trial regressions run over the 1990-1995 and 1995-2000 sub-periods (see Note 27), along with the statistical evidence presented in the Introduction,, suggest that the changes took place mainly in the second part of the 1990s.
} 
dynamic developing economies.

Therefore, contrary to the case of developed countries, the dynamics of services exports contributed relatively less to overall economic growth in the developing regions in the globalizing and liberalizing 1990s than during the previous decade. Such a diverging evolution of the services exports/GDP nexus between developed and developing countries is likely to be attributable mainly to structural factors. Broadly speaking, developed and developing countries do not export the same kinds of services. Developed countries have been experiencing a boom in advanced, technology- and skill-intensive services sectors, which are still nonexistent or embryonic in most developing countries (with some important exceptions, i.e. India; see Arora, 1999; ILO, 2001; Teltscher 2002). Conversely, services exports in developing countries tend to stem mainly from the least advanced and less dynamic services sub-sectors. These sub-sectors are also characterized by a high level of external dependence (in terms of ownership, management, technology, finance, and $\operatorname{trade}^{32}$ ) and, in a parallel fashion, by the relative underdevelopment of their forward and backward linkages with the rest of the domestic economy.

The weight of these structural weaknesses of the services sector in developing countries, moreover, is likely to have been magnified by the tendency towards laissez faire, and trade and financial liberalization, that prevailed in both the domestic and the international policy environments during most of the decade of the 1990s. Responding to the intellectual stimuli stemming from the Washington consensus, and to the more concrete pressure stemming from Washington-based international financial institutions, governments in many developing countries scrambled to spur exports growth, often sacrificing other legitimate policy goals. As Easterly (2001) has shown, the trade ratio (a basic openness indicator) in most developing countries increased substantially up to 1997,33 although it subsequently dropped under the impact of the East Asian crisis. With the benefit from insight, it is arguable that the priority accorded to export expansion often went beyond what would had been advisable, as the pay-off in terms of GDP growth was in fact

\footnotetext{
${ }^{32}$ Ceteris paribus, the least each dollar worth of services (or merchandise) exports contributes to relieve the external constraint (i.e., the lower its positive contribution to the current account balance, net of the imports needed to generate it in the first place), the lower its positive impact on growth (of the economy as a whole) is likely to be.

${ }^{33}$ Easterly (2001) shows that the median Export/GDP ratio in developing countries increased strongly from the late 1980s up to 1997, and fell afterwards (Fig. 6c, p. 35).
} 
disappointing. ${ }^{34}$

\section{Conclusions}

During the last two decades of the 20th Century, the share of the developing countries in total world services exports increased progressively, reaching almost $1 /$ 4 of the world total in 2000 . However, developing countries did not escape from a generalized slow-down in international trade in services. Developing countries' ability to import services also declined sharply, with serious consequences to their overall economic performances.

The econometric analysis presented in this paper shows that services exports do have a positive impact on GDP growth in developing countries. Yet, for developing countries, the services exports/GDP growth nexus is weaker than in the case of developed countries. Moreover, in developing countries, the growth-enhancing impact of exports as a whole appears to have declined in the 1990s, although this decline appears to be due more to the merchandise component of exports rather than to the services component. A tentative explanation for these results is as follows. Export-oriented services activities in most developing countries are poorly integrated to the rest of the domestic economy, besides being often under the control of foreign economic agents. The modalities and sequencing of trade and financial liberalization policies were sub-optimally designed and implemented, due both to domestic and external factors and constraints, among them the fact that the reforms were often carried out under conditions of duress and financial starvation. Domestic resources were diverted toward exports as a goal per se, rather than in the framework of a comprehensive long-term growth-maximizing strategy. As a result, the opening-up reform process in many previously inward-oriented developing countries has been facing diminishing returns.

Received 18 April 2005, Accepted 12 December 2005

\section{References}

Akyuz and Gore (1996), The investment-profit nexus in East Asian industrialization, World Development, 2483), pp. 461-470.

\footnotetext{
${ }^{34}$ Median per capita growth in developing countries during the $1980-1998$ period was 0.0 percent
} (Easterly 2001, p. 3). 
Arora A and Arunachalam V (1999). The Indian software services industry. Carnegie Mellon University Heinz School Working Paper, Pittsburgh, PA, 19 December.

Bahmani-Oskoee M, Mohtadi H, and Ghiath S (1991). Exports, growth and causality in LDCs: A re-examination. Journal of Development Economics, 36(2): 405-415.

Balassa B (1978). Exports and economic growth: Further evidence. Journal of Development Economics, 5(2): 181-189.

Beckerman W (1965). Demand, exports and growth. In: Beckerman W and Associates, eds. The Britain Economy in 1975, The National Institute of Economics and Social Research, Series 23, Cambridge University Press, Cambridge UK: 44-72.

Biswal B and Dawan U (1998). Export-led growth hypothesis: Cointegration and causality analysis for Taiwan. Applied Economic Letters, 5(11): 699-701.

Catao L (1998). Mexico and export-led growth: The Porfirian period revisited. Cambridge Journal of Economics, XXII(1): 59-78.

Chandra R., 2003, Reinvestigating Export-Led Growth in India Using a Multivariate Cointegration Framework., The Journal of Developing areas, Vol.37, Number 1.

Chow P (1987). Causality between export growth and industrial development: Empirical evidence from the NICs. Journal of Development Economics, 26: 55-63.

Easterly W (2001). The lost decades: Developing countries' stagnation in spite of policy reform 1980-1998, World Bank, Washington D.C. (mimeo).

Edwards S (1993). Openness, trade liberalization, and growth in developing countries. Journal of Economic Literature, 31: 1358-1393.

Ekanayake E (1999). Exports and economic growth in Asian developing countries: Cointegration and error-correction models. Journal of Economic Development, 24(2): 4356.

Fedor G (1992). On exports and economic growth. Journal of Development Economics, 12(1): 59-73.

Gabriele A., 2004, International trade in services and the evolving position of developing Countries, Journal of Economic Integration, 19(4), December

Giles J and Williams C (2000). Export-led growth: A survey of the empirical literature and some non-causality results, Part 1. Journal of International Trade and Economic Development, 9: 261-337.

Glasure Y and Lee A (1999). The export-led growth hypothesis: The role of the exchange rate, money and government expenditure for Korea, Atlantic Economic Journal, 27(34).

Haberlar G (1959). International trade and economic development, National Bank of Egypt, Fiftieth Anniversary Commemoration Lectures, Cairo.

Helpman E and Krugman P (1985). Market Structure and Foreign Trade, MIT Press, Cambridge.

ILO (2001). Life at work in the information economy, World Employment Report 2001, Geneva.

Islam M (1998). Export expansion and economic growth: Testing for cointegration and causality. Applied Economics, 30: 415-425.

Jin J.C. (1995). Export-led growth and the four Little Dragons, Journal of International 
Trade and Economic Development, 4:203-215.

Jin J.C.(2002). Exports and growth: Is the export-led growth hypothesis valid for provincial economies?, Applied Economics, 34(1): 63-76.

Johnston J (1984). Econometric Methods, $3^{\text {rd }}$ ed., New York, Macmillan Publishing Company.

Jung W. and Marshall P (1985). Exports, growth and causality in developing countries, Journal of Development Economics, No. 18: 1-12.

Khalifa Al-Youssif Y (1997). Exports and growth: Some empirical evidence from the Arab Gulf States, Applied Economics, 29(6): 693-7.

Langhammer R (2002). Developing countries as exporters of services: What trade statistics suggest. Journal of Economic Integration, 17(2): 297-310.

Levin A and Raut L (1997). Complementarities between exports and human capital in economic growth: Evidence from the semi-industrialized countries. Economic Development and Cultural Change, 46: 155-174.

Mela C and Kopalle P (2002). The impact of collinearity on regression analysis: The asymmetric effects of negative and positive correlations, Applied Economics, 34 (6): 667-677.

NASSCOM (National Association of Software and Services Companies) (2002). Software Exports. See www.nasscom.org/it_industry/SW_export.asp.

OECD (2000). Information technology outlook: ICTs, e-commerce and the information economy, OECD, Paris.

Ram R (1985). Exports and economic growth: Some additional evidence. Economic Development and Cultural Change, 33: 415-25.

Richards D (2001). Exports as a determinant of long-run growth in Paraguay, 1966-1996. Journal of Development Studies, 38(1): 128-146.

Rodriguez F and Rodrik D (1999). Trade policy and economic growth: A skeptic's guide to the cross-national evidence, NBER Working Paper 7081, National Bureau of Economic Research, Cambridge MA.

Sharma S and Dhakal D (1994). Causal analysis between exports and economic growth in developing countries. Applied Economics, 26(12): 1145-1157.

Shan J and Sun F (1998). On the export-led growth hypothesis for the Little Dragons: An empirical investigation. Atlantic Economic Journal, 26(4).

Sheehey E (1990). Exports and growth: A flawed framework. The Journal of Development Studies, 27(8): 111-116.

Teltscher S (2002). Export competitiveness and e-services. UNCTAD, Geneva (mimeo).

Vernon R (1966). International investment and international trade in the product cycle. Quarter Journal of Economics, No.80: 290-307.

WTO (1997). A review of statistics on trade flows in services, Note by the Secretariat. S/ C/W/27/Add.1, Geneva. 